\title{
La censura teatral a Espanya durant el franquisme. El cas de la traducció de La gata sobre el tejado de zinc, de Tennessee Williams
}

\author{
JORDI VILARÓ BERDUSAN \\ Grup d’Estudis de Literatura Catalana Contemporània (GELCC-UAB, Espanya) \\ orcid.org/0000-0002-9099-4445
}

Presentació: 15 nov. 2018 | Acceptació: 25 nov. 2018 | Publicació: 15 des. 2018

Citació recomanada: Vilaró Berdusan, Jordi. 2018. «La censura teatral a Espanya durant el franquisme. El cas de la traducció de "La gata sobre el tejado de zinc", de Tennessee Williams». Dictatorships \& Democracies. Journal of History and Culture 6: 213-231. doi: https://dx.doi.org/ 10.7238/ dd.voi6.3157.

Resum: Aquest article té com a objectiu oferir una panoràmica general del desenvolupament i l'evolució de la censura teatral a Espanya durant el franquisme: s'hi expliquen els mecanismes, els criteris i els procediments que utilitzaven a l'hora de censurar un text teatral les diferents institucions franquistes creades ad hoc amb l'objectiu de controlar tota expressió artística hostil a les idees del règim. També s'hi examina un exemple de censura teatral aplicada a la traducció d'un text de teatre estranger: La gata sobre el tejado de zinc, de Tennessee Williams, traduïda al castellà per Antonio de Cabo.

Paraules clau: censura teatral, franquisme, institucions franquistes, Tennessee Williams, Antonio de Cabo

The Theatre Censorship in Spain during Francoism. The Case of the Translation of Tennessee Williams' La Gata sobre el Tejado de Zinc

Abstract: The objective of this article is to provide a general overview of the development and evolution of theatrical censorship in Spain during Franco regime: it displays the mechanisms, the criteria and procedures used to censor a theatrical play by the Francoist institutions created ad hoc with the aim to control any possible artistic expression hostile to the regime ideas. The article also examines an example of theatrical censorship applied to the translation of a foreign theatre play: Tennessee Williams' Cat on a Hot Tin Roof, translated into Spanish by Antonio de Cabo.

Key words: theatrical censorship, Francoism, Francoist institutions, Tennessee Williams, Antonio de Cabo 


\section{La institucionalització de la censura teatral franquista}

El 22 d'abril de 1938 els Servicios de Prensa y Propaganda del Ministerio del Interior franquista, que encapçalava Dionisio Ridruejo, van promulgar la Ley de Prensa amb la intenció de regular la intervenció de la censura en els mitjans de comunicació. L'Estat franquista que sorgeix de la Guerra Civil, doncs, va començar a construir l'edifici institucional i burocràtic de la censura per mitjà de la creació de tot un seguit d'organismes que tenien com a objectiu el control del cinema i del teatre. Amb aquest propòsit, el 5 de novembre de 1938 es va instituir la Junta Nacional de Teatros y Conciertos. El març del 1940 aquesta junta va passar a denominar-se Consejo Nacional de Teatros i es va designar com a comissari Luis Escobar i com a subcomissaris Claudio de la Torre i Huberto Pérez de la Ossa.

El desembre del 1938, el Ministerio del Interior, encapçalat per Ramon Serrano Súñer, va absorbir el Ministerio de Orden Público, que va passar a anomenar-se Ministerio de Gobernación, amb tres subsecretaries, una de les quals era el Servicio de Prensa y Propaganda, de què depenien els Servicios de Teatro y Cinematografía. La censura teatral oficial, però, es va iniciar el 15 de juliol de 1939, quan es va publicar al Boletín Oficial del Estado la creació de la Sección de Censura, que depenia de la Jefatura del Servicio Nacional de Prensa y Propaganda. En el preàmbul d'aquesta secció, se n'exposa la justificació doctrinal:

En distintas ocasiones ha sido expuesta la necesidad de una intervención celosa y constante del Estado en orden a la educación política y moral de los españoles [...] Con objeto de que los criterios que presiden esta obra de educación posean en todo momento unidad precisa [...] conviene crear un organismo único, que reciba la norma del gobierno y la realice [...] en cada caso particular. ${ }^{1}$

L'abast d'aquesta secció ja quedava prou explícit en l'article 2 de la mateixa llei, en què es reglava que la censura s'aplicaria en els casos següents:

1 Orden de 15 de julio de 1939 creando una Sección de Censura dependiente de la Jefatura del Servicio Nacional de Propaganda, Boletín Oficial del Estado, núm. 211 (3o jul. 1939): 419-4120. 
$1^{0}$ A toda clase de publicaciones no periódicas, y de aquellos periódicos ajenos a la jurisdicción del Servicio Nacional de Prensa.

$2^{\circ}$ A los originales de obras teatrales, cualquiera que sea su género.

$3^{\circ}$ A los guiones de películas cinematográficas. ${ }^{2}$

D’altra banda, també s'indicava clarament que la publicitat dels autors originals era condicionada a l'autorització prèvia de la Sección de Censura.Aquesta secció, per tant, va centralitzar des de llavors la vigilància que s'exercia de feia temps sobre manifestacions culturals de tota mena: el teatre era una de les expressions culturals més escrutades per la censura.

La secció tenia competència per exercir la censura sobre qualsevol gènere teatral, és a dir, «todas las obras que revisten carácter de drama, melodrama, comedia o sainete, entremés, zarzuela, opereta y revista» (Jefatura Provincial de Propaganda, Sección de Censura Intelectual, «Normas», citat per Gallofré 1991, 504). El procediment per a qualsevol estrena era sempre el mateix: la secció havia de rebre dos exemplars de les obres teatrals que haguessin de representar-se, i aleshores emetia un full de censura vàlid per a tot l'Estat. Des de les Jefaturas Provinciales de Propaganda, més endavant convertides en delegacions provincials del Ministerio de Información y Turismo, se sollicitaven còpies d'aquests fulls de censura per comprovar que les obres que s'havien de representar estaven controlades. En cas que no ho haguessin estat, se n'enviaven dos exemplars a Madrid. Aquests exemplars es tornaven segellats per la Sección de Censura del Departamento de Teatro, juntament amb un certificat de censura en què s'indicaven les condicions imposades per a l'aprovació. En el certificat de censura s'hi feia constar la qualificació obtinguda, les possibles restriccions i les parts ratllades, que podien ser paraules, frases o expressions no autoritzades. És important de remarcar, però, que la censura d'espectacles era independent de la de textos teatrals. Com comenten Sharon Feldman i Francesc Foguet $(2016,52)$, des del 1942 «la censura de representacions depengué del Departamento de Teatro de la Sección de Cinematografía y Teatro, mentre que la de l'edició de textos dramàtics fou assumida di-

2 Ibídem. 
rectament per la Delegación Nacional de Propaganda de la Vicesecretaría de Educación Popular».

El final de la Segona Guerra Mundial va comportar que el règim franquista fes un gir cap a les forces aliades guanyadores del conflicte bèllic, cosa que es va traduir en una pèrdua de pes del sector falangista en el Govern a favor del catòlic integrista. ${ }^{3}$ En coherència amb aquesta nova política, Franco va suprimir la Vicesecretaría de Educación Popular — supeditada a la Secretaría General del Movimiento, sota control dels falangistes-, de manera que les seves funcions van passar a càrrec de la nova Subsecretaría de Educación Popular, integrada en el Ministerio de Educación Nacional, en mans de catòlics. D’aquesta nova subsecretaria en dependria la Dirección General de Cinematografía y Teatro, que comprenia la Junta de Censura. El 1951 les competències de la Subsecretaría de Educación Popular van passar al Ministerio de Información y Turismo, que encapçalava el catòlic integrista Gabriel Arias-Salgado. Aquesta remodelació de gabinets i de juntes va tenir com a conseqüència un enduriment de la censura, situació que va durar fins a la fi del mandat d'Arias-Salgado el 1962.

Pel que fa a la redacció d'una normativa de censura, la Comisión Episcopal de Ortodoxia y Moralidad, d'acord amb la Dirección Central de Acción Católica, va aprovar el febrer del 1950 les «Instrucciones y normas para la censura moral de espectáculos» alhora que va crear, també, la Oficina Nacional de Vigilancia de Espectáculos, organisme que depenia de la Comisión Episcopal i que s'encarregava de l'aplicació de les normes a tot l'Estat. Aquesta oficina integrava tots els anteriors organismes de caràcter privat.

Els certificats de censura eren elaborats pels censors ${ }^{4}$ civils i eclesiàstics, que analitzaven l'obra avaluant amb especial atenció els aspectes temàtics següents: la política, a fi d'eliminar qualsevol crítica al règim, al dictador, a l'Exèrcit, als cossos oficials de l'Estat, entre d'altres; la religió, per tal de

3 En aquesta línia d’apertura i aproximació aliadòfila es promulga el Fuero de los Españoles, que estableix els drets i deures dels espanyols i declarava que «todo español podrá expresar libremente sus ideas mientras no atente a los principios fundamentales del Estado» (art. 12), Fuero de los Españoles, Boletín Oficial del Estado, núm. 199 (18 jul. 1945):358. Aquesta restricció genèrica a una llibertat d'expressió abstracta va ser el suport legal amb què els censors autoritzaven o prohibien el que calgués.

4 Els censors no eren personal funcionari, sinó que eren contractats per la Junta de Censura Teatral (Junta de Censura de Obras Teatrales a partir del 1963). D’alguna manera, representaven les diferents famílies ideològiques del règim. 
suprimir atacs contra l'Església catòlica, les seves normes i els dogmes, i la societat, per esborrar tot el que anés en contra de les bones maneres, amb especial atenció al sexe, a l'erotisme i al llenguatge indecorós o provocatiu.

Així doncs, tal com assenyala Manuel L. Abellán (1980, 89) els criteris de censura tractaven tant l'àmbit ideològic com el moral, i es regien pels preceptes següents:

1. Moral sexual entendida como prohibición de la libertad de expresión que implicaba, de alguna manera, un atentado al pudor y a las buenas costumbres en todo lo relacionado con el sexto mandamiento y, en estrecha unión con dicha moral, abstención de referencias al aborto, homosexualidad y divorcio.

2. Opiniones políticas en el sentido en que se ha apuntado más arriba [és a dir, la prohibició de tota obra que mostrés hostilitat cap al règim].

3. Uso del lenguaje considerado indecoroso, provocativo e impropio de los buenos modales por los que se ha de regir la conducta de las personas que se autodefinen como decentes.

4. Por último, la religión como institución y jerarquía, depositaria de todos los valores divinos, humanos e inspiradora de la conducta humana arquetípica.

Pel que fa al teatre estranger traduït, a més d'aquest control extern que exercien les autoritats franquistes sobre el text de la representació, cal afegir-hi, també, la censura interna, és a dir, aquella censura que aplicava el mateix traductor sobre l'obra traduïda abans de ser enviada a l'aparell de censura. La por a la prohibició o a la denúncia feia que els traductors fossin curosos i se sotmetessin a l'autocensura, per la qual d'entrada ja no es traduïen temes controvertits o expressions dubtoses. Ara bé, tal com apunta Maria Pérez López de Heredia (2004, 52), aquesta autocensura també podia obeir a raons que anessin més enllà de les estrictament polítiques i morals: a més de preparar un text per obtenir l'autorització oficial, el traductor també maldava per aconseguir que l'obra fos acceptada pel públic a fi que la producció resultés rendible a l'empresari. Per aquest motiu calia que el traductor s'adaptés al sistema escènic i al mercat cultural per als quals treballava. Així, per exemple, les obres de teatre de la Gran Bretanya generalment s'escurçaven quan es traduien, atès que 
el públic espanyol estava acostumat a representacions més breus que el britànic. Piedad de Salas $(1965,19-21)$ explica prou bé aquest procés moral, ideològic i cultural:

Respecto a las obras traducidas que se representan en los teatros, podemos decir que, en la mayoría de los casos, no se trata de traducciones propiamente dichas, sino de "versiones", de "adaptaciones" a la manera española, en que el adaptador se permite las mayores libertades, sobre todo con las obras escabrosas. En el léxico teatral eso se llama "peinar", equivalente al "afeitado" de los toros. Rara es la obra que no ha sido cortada, porque el horario de espectáculos en España es más breve que en otros países y el aguante del público, también.

En tots els informes enviats a les instàncies jeràrquiques superiors, s'hi consignava breument l'argument de l'obra i el seu valor purament literari i teatral, i s'indicava, acompanyant el judici o avaluació que cada censor feia de l'obra, si en el text hi ha havia cap matís polític o religiós suspecte. El lector proposava una sèrie d'omissions, addicions o canvis que l'obra hauria d'incloure perquè es pogués representar, i assenyalava fins i tot les pàgines, els actes i escenes en què caldria incloure aquestes modificacions. En general, el text, que ja havia passat per l'autocensura del traductor, acostumava a autoritzar-se sense excessius canvis. En tot cas, les qualificacions que l'obra podia obtenir eren les següents:
1. Aprobada
2. Aprobada con tachaduras
3. Aprobada a reserva del ensayo general
4. Aprobada por un número limitado de representaciones
5. Autorizada para menores de 14 años
6. Prohibida ${ }^{5}$

5 María Pérez López de Heredia, «Traducción y censura en la escena española de postguerra. Creación de una nueva identidad cultural», dins Traducción y censura Inglés-Español 1939-1985 (León: Universidad de León, 2000), 165. 
Amb tot, la censura estava controlada per gent molt diversa i, per tant, malgrat les instruccions promulgades, no hi havia uns criteris legals ben definits. Si bé tota obra que aspirés a ser estrenada per una companyia de teatre s'havia de sotmetre als mecanismes de censura esmentats, les normes reguladores d'aquests mecanismes no eren fàcils de concretar, ja que fins al 1963 el règim no va elaborar un corpus normatiu concret, sinó que va resoldre cada cas individualment, de manera que obtenir el permís de representació anava lligat més al criteri del censor de torn que no pas al compliment d'una normativa específica determinada i concreta.

\section{La traducció d’Antonio de Cabo de La gata sobre el tejado de zinc, de Tennessee Williams}

La traducció d'Antonio de Cabo de Cat on a Hot Tin Roof (La gata sobre el tejado de zinc), de Tennessee Williams, és un bon exemple d'aquesta arbitrarietat a l'hora d'avaluar la idoneïtat d'un text teatral, atès el periple que va haver de passar l'obra abans que les autoritats censores de torn no n’autoritzessin la representació. Vegem-ne el procés.

Després d'una primera sollicitud, no es va autoritzar la representació de l'obra a causa de l'informe negatiu emès pels dos censors, molt especialment pel criteri del pare Andrés Avelino Esteban Romero:

Es muy difícil encontrar una apoyatura moral en la trama de esta comedia para aprobarla. Pertenece a ese género de teatro moderno, descarnado y crudo, en el que se toma, no la vida como es, sino lo peor que hay en la vida en determinados ambientes, para llevarlo a la escena. Esto es "Una Gata SObRe un teJAdo..."

La vida en una familia americana, dueño el cabeza de ella de una rica y extensa plantación — 14.0ooh - en el Delta del Misisipí. Pero qué familia! Tal son todos, padres, hijos, nueras, nietos, que el título más expresivo hubiera sido la exclamación antes dicha: iiiVaya familia!!!

Tal vez la adaptación española, ante la crudeza de la trama en torno al personaje que le da título y que lógicamente parece que debiera ser el capital, MARGARET, la esposa de Brick, uno de los hijos del Abuelo, ha hecho que la obra aparezca purificada en la versión española. Efectivamente, la trama MARGARETBRICK, queda en gran parte de la comedia desplazada, por la trama de el ABU- 
ELO-BRICK primero, y con todos los familiares después. No tiene más unidad que la genérica de toda una familia en desorden moral, afectivo y hasta social.

El sentido moral no tiene en toda la trama más síntomas que el considerar que la borrachera hasta alcoholizarse es repulsiva; y que es bueno que las mujeres casadas tengan hijos... Fuera de estos síntomas de una moral natural, en toda la trama juegan los odios entre los hermanos, cuñadas, padres e hijos, esposos, etc. etc. Léase como ejemplo todo el ACTO II... El coloquio del padre con el hijo BRICK, hablándole de su propia madre y de sus relaciones no claras con un personaje que no entra en escena, es prototipo de un sentido de la vida familiar y de las relaciones de padres e hijos que no puede estar más en contra del sentido cristiano de la vida de familia. Y así en muchos otros aspectos. El mismo título de la comedia es ya todo un símbolo de las relaciones entre MARGARET y BRICK, su marido...

Yo estimaría que esta comedia, por respecto al nombre del autor, podría autorizarse para representaciones de Cámara. ${ }^{6}$ Veo muy duro y atrevido darla en representaciones libres, sin una profunda poda, que sobre las adaptaciones que supongo ya lleva, la dejaría excesivamente mutilada con notable daño al sentido del original.

Madrid, 30 de septiembre de 1958

A. Avelino Esteban Romero ${ }^{7}$

6 Teatro de Cámara era un grup de teatre creat a Barcelona l'any 1949 per Antonio de Cabo i Rafael Richart. El primer va assumir el càrrec de director escènic, i el segon, de director artístic. Tots dos s'encarregaven de la gestió teatral del grup. A partir de l'experiència precedent del Teatro Estudio de Juan Germán Schroeder, l’objectiu de Teatro de Cámara era donar a conèixer al públic barceloní el teatre estranger contemporani que els empresaris teatrals no volien o no podien programar. No es tractava d'oferir teatre experimental o inèdit, sinó de representar autors i obres de referència que, malgrat el seu èxit internacional, no podien arribar als circuits professionals habituals. Les estrenes de Teatro de Cámara consistien en una sola representació i s’adreçaven necessàriament a un públic minoritari. Aquest fet va suposar que la censura fos un xic més permissiva amb les obres que estrenaven, atesa la poca projecció popular de les representacions.

7 Expedient de censura número 228-58, Subsecretaría de Educación Popular, Dirección General de Cinematografía y Teatro, Sección de Teatro, Archivo General de la Administración (AGA). Els informes de censura, les resolucions consegüents de la Sección de Teatro i les cartes d’Antonio de Cabo i Tennessee Williams es troben als annexos de la tesi doctoral de Jordi Vilaró Berdusan, «La recepció del teatre de Tennessee Williams a Barcelona durant el franquisme», tesi doctoral (Universitat Autònoma de Barcelona, 2017). 
D'altra banda, l'informe del segon censor, Gumersindo Montes Agudo, va ser més suau, però també va trobar objeccions a l'obra:

Obra realista, áspera, morbosa. La adaptación ha cuidado escenas y sobre todo expresiones que en el original son muy crudas. Aun así no es obra que se caracterice precisamente por su limpieza. Considero que puede autorizarse, no obstante, porque perniciosa no es. Y algunos excesos dialécticos que aparecen son realmente inevitables. (Sugiero que se utilice la puesta en escena para que el tono pasional sea contenido y no derive - sobre todo en Brick- en una equívoca tensión de mal gusto). ${ }^{8}$

L'informe final de la Sección de Teatro de la Dirección General de Cinematografía y Teatro va ser clar:

Vistos los informes emitidos por los Lectores de este Departamento, D. Gumersindo Montes Agudo y Reverendo Padre Andrés Avelino Esteban Romero, sobre la comedia en tres actos original de Tennessee Williams, en versión y adaptación de D. Antonio de Cabo y D. Luis Álvarez, titulada "UnA Gata soBRE UN TEJADO (DE ZINC) CALIENTE", esta Sección tiene el honor de proponer la prohibición de la misma.

Madrid, 2 de octubre de $1958 .{ }^{9}$

En conèixer el veredicte dels censors, Antonio de Cabo va escriure a Tennessee Williams per demanar-li permís per introduir modificacions a la traducció i l'escriptor li va respondre afirmativament:

Dear Antonio de Cabo:

Thank you for the letter in which you informed me about the near-opening of my play, in Madrid, CAT ON A HOT TIN ROOF.

8 Expedient de censura número 228-58, Subsecretaría de Educación Popular, Dirección General de Cinematografía y Teatro, Sección de Teatro, AGA.

9 Expediente de censura número 667-58, Subsecretaría de Educación Popular, Dirección General de Cinematografía y Teatro, Sección de Teatro, AGA. 
I here by consent to permit you to make certain changes in the above named play, such changes, however, will not alter the theme, plot, characters or development of the play as written by me originally.

I had already given you my consent for the changes you made in my play, THE ROSE TATTOO, which I personally saw in Madrid and which made a very good impression on me. I am therefore, giving you my confidence with respect to various changes need for the Spanish version of CAT ON A HOT TIN ROOF knowing you will show the same discretion and ability as you have in the past as adaptor and director of my play.

I would like to be kept informed about the outcome of CAT ON A HOT TIN Roof in Spain because it is important to me that this play meets with success in your country, a country which I enjoy very much.

Sincerely,

Tennessee Williams ${ }^{10}$

De Cabo va aprofitar aquesta autorització de l'autor per tornar a sollicitar el permís de representació a les autoritats argumentant que l'obra s'havia tornat a revisar i que s'havien introduït noves modificacions amb el vistiplau del mateix autor. A més, s'apellava també al fet que l'obra estava assolint un gran èxit mundial, sobretot arran de la versió cinematogràfica de Richard Brooks (1958). El guió cinematogràfic original, que Tennessee Williams i Richard Brooks ja havien alterat per poder passar l'estricta censura cinematogràfica estatunidenca i poder estrenar l'obra a Hollywood, és justament el que Williams va facilitar a De Cabo perquè introduís les modificacions necessàries per a la versió teatral espanyola. De fet, la censura americana no estava gaire allunyada de l'espanyola a l'hora d'aplicar estrictes codis morals als guions cinematogràfics, ja que, a diferència del que succeïa amb el públic teatral, es buscava de preservar el públic de cinema de segons quins discursos, com Pérez López de Heredia $(2004,187)$ ha apuntat amb encert: 
Se aprovecha la adaptación cinematográfica para acomodar el texto teatral a los patrones ideológicos de la España franquista, no tan alejados de los estrictos parámetros morales patrocinados por la censura cinematográfica de Hollywood cuya industria, al amparo de un estricto código moral, se había construido sobre un tipo de producción muy distinto a la práctica discursiva divulgada por Cat on a Hot Tin Roof. De hecho, los cineastas estadounidenses, además de cumplir con las demandas de censura, tienen que ser muy cuidadosos con el gran público cinematográfico, mucho más conservador que el público teatral, de forma que se adecuan a él, favoreciendo una visión idealizada de los valores norteamericanos.

Les autoritats van tornar a revisar llavors la traducció i en van emetre un nou informe, aquest cop favorable als interessos de la companyia. Amb tot, el censor, el pare Avelino Esteban Romero, encara va mostrar reticències i fins i tot va demanar una segona opinió per acabar d'autoritzar la representació de l’obra:

\section{Informe moral:}

Informé sobre esta Comedia el 30 de septiembre pp. No me atreví a emitir informe aprobatorio bajo el aspecto moral, para representaciones comerciales, limitando mi tolerancia a representaciones de Cámara.

Hoy vuelve la comedia con algunas adaptaciones, expresamente autorizadas por el propio autor para la versión española, según informe que se adjunta al expediente. También se incluye el guion castellano de la película, rodada por la Metro, y que está ya circulando por el mundo.

He vuelto a examinar, detenidamente, esta nueva versión de "UNA GATA..." Conserva, como es lógico, su dureza argumental, su trama áspera, su desenlace crudo con la victoria de los deseos de la "gata”. Pero he de reconocer que ha sido suavizada en algunos de los diálogos más directos, tanto entre BRICKMARgARET - los esposos en desacuerdo-como entre BRICK-ABUELO-PADRE E HIJO. Tal como queda en esta versión estimaría que esta comedia no es más cruda que Panorama desde el puente, de Miller; o que la rosa tatuada, del mismo Tennessee. En la misma línea están Sur y Té y simpatía, que pa- 
saron, con el máximum de elasticidad en los criterios. Creería lógico aplicar a “UnA GATA..." la misma medida de juicio.

\section{Observaciones generales}

Ya hacía notar en mi informe anterior que, sin duda, por las adaptaciones introducidas en la versión española, esta obra, de renombre y éxito teatrales en todo el mundo, tenía una bifurcación de interés argumental, que no era el exigido por su título mismo. Efectivamente, en todo el ACTO SEGUNDO, la "GATA..." encarnada en MARGA, la esposa de BRICK, pasa a segundo plano, ganando la atención el problema planteado por el largo diálogo ente el ABUELO-BRICK, acerca de la verdad y la mentira, la ficción y el disimulo en que se mueven los hombres. Diría que en la trama juegan ambos problemas, el uno en función casual del otro. En el desenlace, con todo, reaparece el tema de la obra, logrando MARGA, la "gata", reconquistar a su marido BRICK, hasta el punto que accede a volver al lecho conyugal. Este desenlace, menos claro en la obra teatral, está directamente indicado en el "Guion" que se adjunta al informe, y que es obra del mismo autor.

\section{$\underline{\text { Inconvenientes }}$}

El único es integral: la ambientación de un drama familiar en un clima no cristiano. En consecuencia la idea que se expresa del matrimonio, de las relaciones de padres e hijos, de algunos valores morales, etc., nos resulta estridente a nuestros oídos cristianos. He de advertir, con todo, no es provocativo ese clima, especialmente, con algunas adaptaciones que señalo más abajo. El estilo, más que apologético de un determinado modo de ser familiar, es narrativo, realista, en torno a unos tipos humanos inferiores, y a los que no se justifica nunca en su desorden. Al contrario, se les ataca en sus anomalías. Especialmente se reprueba el alcoholismo de BRICK. Y el problema subyacente -la sospechosa relación entre BRICK-SKEEPER [sic], este último personaje de referencia tan solo - encuentra la general desaprobación de todos, y hasta el mismo BRICK insiste en negar toda morbosidad a esa amistad entre dos hombres. MARGARET, la "gata”, consigue, al fin, reconquistar a su marido, a través de una mentira, derrochando pasión en el empeño. Y el marido accede, al fin, 
a volver con su mujer al lecho conyugal. El desenlace no es del todo aceptable, ya que el fin no justifica los medios. Pero el deseo de la esposa de recobrar a su esposo triunfa por encima de la resistencia de aquel y a pesar de las intrigas familiares, motivadas por cuestiones de herencia ante la muerte inminente del Abuelo, atacado de cáncer.

\section{$\underline{\text { Adaptaciones }}$}

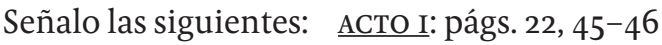

ACTO II: págs. 24, 31, 35, 47

Estas adaptaciones no cambian el carácter de los personajes ni merman el interés dramático de la trama, no desfiguran la línea argumental. Tan solo descargan un tanto [sic] algunas expresiones más crudas, que revelan criterios enteramente opuestos a la moral cristiana.

El título lo encuentro un tanto equívoco: “UNA GATA SOBRE UN TEJADO DE ZINC CALIENTE”... Y según su intérprete puede resultar más o menos crudo a los oídos españoles. Sería de desear que en castellano quedase tan solo en "UNA GATA SOBRE UN TEJADO” o mejor aún: "LA GATA", como se anuncia en algunas versiones extranjeras.

Finalmente, me agradaría que otro censor eclesiástico leyese la obra, para mi tranquilidad. Incluso remitiéndole también el expediente completo, si así lo estima esa Sección.

En todo caso, solo para mayores de 18 años, con limitación de itinerario teatral y de radiodifusión y televisiones.

Madrid, 5 de diciembre de 1958

A. Avelino Esteban Romero ${ }^{11}$

El segon informe, emès pel pare Manuel Villares, va ser favorable a la representació de l'obra:

Luicio general que merece al Censor: La comedia es un sombrío aguafuerte que nos presenta con dramática intensidad el cuadro de una familia domina-

11 Expediente de censura número 667-58, Subsecretaría de Educación Popular, Dirección General de Cinematografía y Teatro, Sección de Teatro, AGA. 
da por la mentira, la envidia, la avaricia y las pasiones más elementales. Pero es una comedia humana, en la que la fuerza con que están descritos los personajes con sus caracteres, duros a veces, hace desaparecer la morbosidad que pudiera tener el asunto.

Desde el punto de vista moral no veo inconveniente en su representación, haciendo las supresiones de diálogo que ya vienen señaladas con lápiz rojo en varios pasajes de la obra.

Finalment, el 19 de gener de 1959, la Sección de Teatro va acabar atorgant l'autorització perquè es representés l’obra:

Esta Sección, vistos los informes emitidos por los censores eclesiástico Rvdo. Padre Avelino Esteban Romero y Rvdo. Padre Manuel Villares, tiene el honor de proponer la autorización de la obra original de Tennessee Williams, traducción de Antonio Cabo y Luis Sáenz, titulada “LA GATA SOBRE EL TEJADO DE ZINC...” Clasificación: Para mayores de 18 años.

La presente autorización solo ampara la representación de la obra a que se refiere en el Teatro Comedia de Barcelona.

No obstante V. I. con mejor criterio resolverá lo más acertado.

Madrid, 19 de enero de $1959 .{ }^{12}$

\section{La censura teatral després de la reforma del 1963}

El 1962 Manuel Fraga Iribarne va ser nomenat ministre d'Información y Turismo en substitució d'Arias-Salgado i va introduir tot un seguit de reformes que tenien el propòsit d'escenificar una certa obertura política del règim —-més estètica que no real, però. José María García Escudero es va situar al capdavant de la Dirección General de Cinematografía y Teatro. Tot i una certa permissivitat pel que fa a certs autors, la censura va continuar funcionant de manera ben activa.

12 Expediente de censura número 17-59, Subsecretaría de Educación Popular, Dirección General de Cinematografía y Teatro, Sección de Teatro, AGA. 
El 1963-1964, la Junta de Censura Teatral va passar a denominar-se Junta de Censura de Obras de Teatro (JCOT). La principal aportació de la JCOT al panorama de censura espanyol va ser l'aprovació per primer cop d'una llei específica amb un règim intern i unes normes detallades i concretes per a la censura. ${ }^{13}$ Aquestes normes s'adreçaven a la censura cinematogràfica, però eren del tot vàlides per al teatre i, de fet, els censors teatrals les van adoptar plenament a l'hora d'aplicar retallades i prohibicions a les obres que havien de valorar. Les normes generals que havien de regir l'avaluació censora des d'aquell moment eren les següents:

Primera. Cada película se deberá juzgar, no sólo en sus imágenes o escenas singulares, sino de modo unitario en relación con la totalidad de su contenido y según las características de los distintos géneros y estilos cinematográficos. Si una película en su conjunto se considera gravemente peligrosa, será prohibida antes que autorizarla con alteraciones o supresiones que la modifiquen en manera sustancial.

Segunda. El mal se puede presentar como simple hecho o como elemento del conflicto dramático, pero nunca como justificable o apetecible, ni de manera que suscite simpatía o despierte deseo de imitación.

Tercera. La presentación de las circunstancias que pueden explicar humanamente una conducta moral reprobable, deberá hacerse de forma que ésta aparezca ante el espectador como objetivamente justificada.

Cuarta. La película debe conducir lógicamente a una reprobación del mal, considerado al menos como atentado contra los principios de la moral natural, pero no es necesario que esa reprobación se muestre explícitamente en la pantalla si se dan elementos suficientes para que pueda producirse en la conciencia del espectador.

Quinta. La reprobación del mal no se asegura siempre de manera suficiente con una condenación en los últimos planos o hecha de modo accidental o marginal; tampoco exige necesariamente el arrepentimiento del malhe-

13 Orden de 6 de febrero de 1964 por la que se aprueba el Reglamento de Régimen Interior de la Junta de Censura de Obras Teatrales y las normas de censura, Boletín Oficial del Estado, núm. 48 (25 feb. 1964): 2504-2506. 
chor ni su fracaso humano o externo. Es conveniente que el mal esté contrapesado por el bien durante el desarrollo de la acción.

Sexta. No hay razón para prohibir la presentación de las lacras individuales o sociales, ni para evitar lo que produzca malestar en el espectador al mostrarle la degradación y el sufrimiento ajenos, si se obedece a los principios de una crítica rectamente hecha y no se atenta a lo dispuesto en estas Normas.

Séptima. No hay razón para prohibir un cine que se limite a plantear problemas auténticos, aunque no los dé plena solución, con tal que no prejuzgue una conclusión inaceptable según estas Normas.

Octava. Se prohibirá: $1^{\circ}$ ) La justificación del suicidio. $2^{\circ}$ ) La justificación del homicidio por piedad. $3^{\circ}$ ) La justificación de la venganza y del duelo. No se excluirá su presentación como simples hechos en relación con costumbres sociales de épocas o lugares determinados, siempre que se evite una justificación objetiva y general. $4^{\circ}$ ) La justificación del divorcio como institución, del adulterio, de las relaciones sexuales ilícitas, de la prostitución y, en general, de cuanto atente contra la institución matrimonial y contra la familia. $5^{\circ}$ ) La justificación del aborto y de los métodos anticonceptivos. Novena. Se prohibirá: $1^{\circ}$ ) La presentación de las perversiones sexuales como eje de la trama y aun con carácter secundario a menos que en este último caso esté exigida por el desarrollo de la acción y ésta tenga una clara y predominante consecuencia moral. $2^{\circ}$ ) La presentación de la toxicomanía y del alcoholismo, hecha de manera notoriamente inductiva. $3^{\circ}$ ) La presentación del delito en forma que, por su carácter excesivamente pormenorizado, constituya una divulgación de medios y procedimientos delictivos.

Décima. Se prohibirán aquellas imágenes y escenas que puedan provocar bajas pasiones en el espectador normal y las alusiones hechas de tal manera que resulten más sugerentes que la presentación del mismo hecho.

Undécima. Se respetará la intimidad del amor conyugal, prohibiendo las imágenes y escenas que la ofendan.

Duodécima. Se prohibirán las imágenes y escenas de brutalidad, de crueldad hacia personas o animales, y de terror, presentadas de manera morbosa o injustificada en relación con las características de la trama y del género cinematográfico correspondiente, y, en general, las que ofendan a la dignidad de la persona humana. 
Decimotercera. Se prohibirán las expresiones coloquiales y las escenas o planos de carácter íntimo que atenten contra las más elementales normas del buen gusto.

Decimocuarta. Se prohibirán: $1^{\circ}$ ) La presentación irrespetuosa de creencias y prácticas religiosas. $2^{\circ}$ ) La representación denigrante o indigna de ideologías políticas y todo lo que atente de alguna manera contra instituciones o ceremonias. En cuanto a la presentación de los personajes, ha de quedar suficientemente clara para los espectadores la distinción entre la conducta de los personajes y lo que representan. $3^{\circ}$ ) El falseamiento tendencioso de los hechos, personajes y ambientes históricos.

Decimoquinta. Se prohibirán las películas que propugnen el odio entre pueblos, razas o clases sociales o que defiendan, como principio general, la división y el enfrentamiento, en el orden moral y social, de unos hombres contra otros.

Decimosexta. Se prohibirán las películas cuyas tesis nieguen el deber de defender la Patria y el derecho a exigirlo.

Decimoséptima. Se prohibirá cuanto atente de alguna manera contra: $1^{\circ}$ ) La Iglesia Católica, su dogma, su moral y su culto. $2^{\circ}$ ) Los principios fundamentales del Estado, la dignidad nacional y la seguridad interior o exterior del país. $3^{\circ}$ ) La persona del Jefe del Estado.

Decimoctava. Cuando la acumulación de escenas o planos que en sí mismos no tengan gravedad, cree, por la reiteración, un clima lascivo, brutal, grosero o morboso, la película será prohibida.

Decimonovena. Cuando las películas se vayan a proyectar exclusivamente ante públicos minoritarios, las anteriores Normas se interpretarán con la amplitud debida, conforme el grado de preparación presumible en dichos públicos. Las películas blasfemas, pornográficas y subversivas se prohibirán para cualquier público.

Vigésima. En casos excepcionales se prohibirán los títulos de las películas que en sí mismos vulneren lo dispuesto en estas Normas o que desorienten a los espectadores, con daño moral de éstos, sobre el contenido real de las películas. ${ }^{14}$

14 Normas de censura cinematográfica, Boletín Oficial del Estado, núm. 58 (8 març 1963): 39293930. Aquestes normes s'aplicarien al teatre per l'ordre del 6 de febrero de 1964 del Ministerio de Información y Turismo (Boletín Oficial del Estado, 25 feb. 1964). 
Entre el 1969 i el 1975, la conflictivitat social del tardofranquisme també va incidir sobre els estaments polítics que regulaven la censura. El 1969 Manuel Fraga Iribarne va ser substituït al capdavant del Ministerio de Información y Turismo per Alfredo Sánchez Bella, catòlic ultradretà que va accentuar la repressió censuradora i va aturar la mínima obertura del període de Fraga al capdavant del ministeri. Per a Sánchez Bella i el seu equip, la censura estricta era del tot necessària per evitar tota manifestació artística que impliqués qualsevol dissidència política. El 1973 Sánchez Bella va ser rellevat per Fernando Liñán Zofío, que aquell mateix any, després de l'atemptat contra Carrero Blanco, va deixar el càrrec a Pío Cabanillas, de tarannà més moderat i liberal. El 1974, per conflictes interns del règim, Cabanillas va cedir el lloc a l'ultraconservador León Herrera Esteban, que va tornar a endurir la política de censura. El 1975 la JCOT va passar a denominar-se Junta de Ordenación de Obras Teatrales, un nom eufemístic que pretenia suavitzar la funció d'una junta que, malgrat tot, va seguir ben activa fins al 4 de març de 1978, quan va entrar en vigor el Reial decret 262/1978 sobre la llibertat de representació d'espectacles teatrals. Es recuperava, així, la llibertat d'expressió sobre els escenaris espanyols després de quatre dècades de censura.

\section{Bibliografia}

Abellán, Manuel L. 1980. Censura y creación literaria en España (1939-1976). Barcelona: Ediciones Península 62.

De Salas, Piedad. 1965. «La traducción de obras teatrales en España». Babel. Revue internationale de la traduction · International Journal of Translation 11, 1.

Feldman, Sharon G., i Francesc Foguet. 2016. Els limits del silenci. La censura del teatre català durant el franquisme. Barcelona: Publicacions de l'Abadia de Montserrat.

Gallén, Enric. 2013. «Traducció i censura teatral sota la fèrula franquista dels anys cinquanta». Quaderns. Revista de Traducció 20: 95-116.

Gallofré Virgili, Maria Josepa. 1991. L'edició catalana i la censura franquista (1939-1951). Barcelona: Publicacions de l'Abadia de Montserrat.

García Ruiz, Víctor. 2013. Los mecanismos de censura teatral en el primer franquismo y «Los pájaros ciegos» de V. Ruiz Iriarte (1948). Alicante: Biblioteca Virtual Miguel de Cervantes.

Informe sobre la censura cinematográfica y teatral. Inèdit. Ministerio de Información y Turismo. Dirección General de Cinematografía y Teatro, 1964 (?). [Sense firmar: José 
María García Escudero (?)]. Biblioteca del Centro de Documentación Cultural del Ministerio de Cultura. Top. 7514.

«Legislación de 1939». Represura. Revista de Historia contemporánea española en torno a la represión y la censura aplicadas al libro. http://www.represura.es/ legislacion_1939.html.

Muñoz Cáliz, Berta. 2007. Expedientes de la censura teatral franquista. Madrid: Fundación Universitaria Española.

Pérez López de Heredia, María. 200o. «Traducción y censura en la escena española de postguerra. Creación de una nueva identidad cultural». Dins Rosa Rabadán, coord., Traducción y censura Inglés-Español 1939-1985. León: Universidad de León.

- 2004. Traducciones censuradas de teatro norteamericano en la España de Franco (1939-1963). Bilbao: Servicio Editorial de la Universidad del País Vasco.

Vilaró Berdusan, Jordi. 2017. «La recepció del teatre de Tennessee Williams a Barcelona durant el franquisme». Tesi doctoral, Universitat Autònoma de Barcelona. 